\title{
DIVERSITY OF LOCAL FRUIT TREES AND THEIR CONTRIBUTION IN SUSTAINING THE RURAL LIVELIHOOD IN THE NORTHERN CAMEROON \\ ${ }^{*}$ Mapongmetsem, P.M., ${ }^{1}$ Kapchie, V.N. ${ }^{2}$ and Tefempa, B.H. ${ }^{3}$ \\ DOI: http://dx.doi.org/10.4314/ejesm.v5i1.5
}

Received $15^{\text {th }}$ December 2011; accepted $2^{\text {nd }}$ February 2012

\begin{abstract}
The northern Cameroon ecosystems harbor a diversity of useful tree species producing non wood forest products (NWFPs). Indigenous fruit trees are very important for the nutritional quality of rural population and contribute to their income. A better knowledge of the potential utilization of these species and the constraints attached to the transformation of their products and commercialization would favor their promotion. Methodological approach included ethno-nutritional and market surveys, and chemical analysis. Results showed that a total of 55 fruit tree species were valued by the farmers. The top sixteen are represented by Adansonia digitata L., Aframomum latifolium (Afz.) K. Schum, Balanites aegyptiaca (L.) Del., Borassus aethiopum Mart, Deatrium microcarpum Guill. et Perr., Diospyros mespiliformis Hochst ex.A.Rich. Haematostaphis barteri Hook F., Hyphaena thebaica (L.)Mart, Parkia biglobosa (Jacq) R.Br.ex.G.Don, Sclerocarya birrea (A.Rich) Hochst, Syzygium guineense var. macrocarpum (Engl.) F. White, Ximenia americana L., Vitellaria paradoxa Gaertn.f, , Vitex doniana Sweet, Tamarindus indica L, and Ziziphus mauritiana Lam. They are the most preferred and the most commercialized. The chemical composition of these fruits showed that $S$. birrea has the highest vitamin C value $(13.60 \mathrm{mg} / 100 \mathrm{~g})$ and $\mathrm{S}$. guineense has the highest amount of total soluble sugars (93.98\% of DW). Oil contents are low for all the fruits evaluated except $C$. edulis with $21.04 \%$ of lipid. Iron value varies from 0.48 to $48.07 \mathrm{mg} / 100 \mathrm{~g}$ respectively for $P$. guajava and $A$. senegalensis. The richest source of calcium and magnesium is $A$. senegalensis (558.74 and $18.20 \mathrm{\mu g} / \mathrm{g}$ respectively). The nutritive potential of the fruit tree species and their dietary applications are important. Species with high nutritious value can be recommended for a domestication program, which is important to diversify agricultural production and to reduce poverty in Northern Cameroon.
\end{abstract}

Key words: Northern Cameroon, Fruits, Marketing, Chemical composition, Domestication.

\section{Introduction}

Sub-Sahara African rural households suffer from food insecurity. Economic crisis and raising global food prices are affecting rural livelihood adversely. A decline in crop productivity of traditional farming systems coupled with growing rural populations implies a necessity to find alternative or complementary sources of supply in order to deal with the growing needs in rural areas (Gouwakinou et al., 2010). Africa is endowed with natural resources. Ecosystems of the northern region of Cameroon have a large variety of non timber forest products (Mapongmetsem, 2008; Mapongmetsem et al., 2008; Mapongmetsem et al., 2010). Unfortunately utility and commercial value of non timber forest products have been overlooked by extension agencies, at the expense of over-promoted exotic fruits (Kalaba et al., 2008; Mapongmetsem et al., 2008). In recent decades there has been a growing interest in the attributes of NTFPs to food security, income generation and poverty alleviation (FAO, 1999) as well as their attributes to the conservation of natural resources (Belcher et al., 2005). They have received increasing attention and are making significant contributions to local economies (Banana, 1996). One way to improve livelihoods with minimal loss of biodiversity and over exploitation is developing strategies for a sustainable harvest of NTFPs through joint/or participatory forest management (Arnold et Perez, 2001; Termote et al., 2008). Among the NTFPs, indigenous fruits trees play important role. Hence, there has been an increased understanding of their contribution in the diet of rural households. They are consumed raw and used as vegetables or spices in the preparation of various meals (Mapongmetsem et al., 2008; Mapongmetsem et al., 2010).

The role of the indigenous fruits in the alimentation of the population, mainly in famine

\footnotetext{
${ }^{1}$ Department of Biological Sciences, University of Ngaoundere, Cameroon

${ }^{2}$ African Research Centre on Bananas and Plantains, Njombe, Douala, Cameroon.

${ }^{3}$ Department of Animal Biology; P.O. Box 812 University of Yaounde I, Cameroon

Corresponding author email: piermapong@yahoo.fr
} 
periods is not undeniable. In general, edible fruits contain various nutritive substances among which the most important are minerals, organic constituents, vitamin $\mathrm{C}$ and growth substances, etc.(Malaisse, 1997; Loura et al., 2000). Despite their contribution in the food diet and uses in medicines, very few information is available on communities' actual use, quality, management and preferences of local fruit trees in the northern region of Cameroon. Very few scientific works have been done on this problematic at the national scale. Tchiégang-Megueni et al. (2001) made a simple inventory of indigenous fruits of the northern Cameroon. Eyog Matip et al. (2006) describe indigenous fruits of Cameroon among which a few from the northern Cameroon. Aboubakar (1998) determine the mineral content of 5 of them. Recently, Noubissie et al. (2011) started the vegetative propagation of Balanites aegyptiaca, Biospyros mespiliformis and Sclerocarya birrea. These products which are currently under evaluated, contribute to the enhancement of the nutrition of rural populations, a better family income and the economy of the country (Lamien et al., 1996). For the product to become commercially important, they must be utilized beyond the national borders. This requires better governmental policies in food technology and processing. The first step is the development of better knowledge of the potential utilization of the various species, products, quality and of the constraints associated with processing and commercialization.

The aim of the present work is to contribute to better understanding of these parameters in Cameroon. This information will help in elaborating appropriate domestication strategies for sustainable management for edible fruit tree species (EFTS) of the region.

\section{Methodology \\ Study Sites}

Investigations were undertaken along a climatic gradient from south to the north covering two agroecological zones: Guinean Highland Savannahs (GHS) and Sudano-Sahelian (SS). The Guinean Highland Savannah corresponds to the Adamawa administrative region whereas the Sudano-Sahelian is represented by those of the North and Extreme north (Table 1). In each region, two divisions were chosen: Djerem and Vina
(Adamawa), Mayo Rey and Mayo Louti (North) then Mayo Kani and Diamare for the Extreme North (Fig.1). The ethnolinguistic groups involved were the following: Dii, Foulbe and Mboum in Adamawa; Mboum, Fali and Foulbe for the North and Moundang, Toupouri and Mousgoum for the Far North. The main activities of these groups are agriculture and animals husbandry.

\section{Household Survey}

A household survey was conducted among 360 farmers distributed in 6 Divisions; using a semi structured questionnaire as the survey instrument. Each farmer was asked to give five most important fruits, the main uses, parts used, the market, the processing, constraints and perception of dynamics. Beside the list of species used, general characteristics of the farmers were recorded. 120 farmers involved were randomly chosen in each Region. After interview, a trip was organised to the savannah for sample collection and identification. Samples which were not identified in situ were taken to the National Herbarium at Yaounde.

\section{Market Survey}

The market survey was concentrated in the Vina division. Four markets among which two rural (Bamyanga, Dang) and two urban (Belabo market, Bantai) were assessed from April to October 2007. The visit frequency in each market was weekly. All the fruit sellers were systematically interviewed each market day and 52 belonging to various ethnic groups (13 per market) were followed during this period. Data collected from them were on the ethnic group of the seller, vernacular name of the fruit sold, experience in the activity, price, harvesting and transportation modes, the sales' unit, market chain, etc. With the accord of the seller, the product is weighted with a scale and photos were also taken. The buyers surprised in buying or eating fruits were informally interviewed.

\section{Sample Preparation and Chemical Analyses}

Fruit pulp samples were peeled washed, sliced into cubes and freeze-dried using an Edwards bench freeze-drier and ground in a Hammer mill into flour. The samples were analyzed in triplicate for moisture, ash, lipid, protein, total soluble and reducing sugars, and vitamin $\mathrm{C}$ contents. The samples moisture and ash contents were analysed using AFNOR methods (AFNOR, 1981). The method used for the vitamin $\mathrm{C}$ determination was 
that of Harris and Ray (1935) which involves a 2, 6-dichloroendophenol method that measures reduced ascorbic acid. Lipids were extracted and estimated by the method using Soxhlet apparatus, described by Bourely (1982). Proteins were determined by Hantzsch method (Devani et al., 1989). Total alcohol-soluble and reducing sugars were determined by spectrophotometric procedure using UV-visible spectrophotometer Ultrospec (Dubois et al., 1956). Minerals were analysed according to the methods described by AFNOR (1986) and Rodier (1978), consisting in mineralization of samples by dry aching in a muffle furnace and a posterior dilution of the ashes with concentrated hydrochloric acid and distilled water. Minerals were measured using a UV-visible spectrophotometer.

\section{Data Analysis}

Data collected were subjected to analysis of variance. Significant means were separated using Duncan Multiple Range Test. Statistical programme used, was Statgraphics plus 5.0.

\section{Results and discussion}

Households exhibited useful knowledge on the uses and the processing of some indigenous fruit. Indigenous fruits are a source of food (fruit and processed products), medicines and means of generating cash that is essential for sustaining rural communities. From the Highland Guinean Savannah to the Sudano-Sahelian zone, 97 - 100\% of households collect fruits which are an important source of food to the households. Primary fruit collectors were women and children. Women are the most concerned because they are in charge of health and feeding of families. The traditional methods of fruit collection are picking, shaking stems and throwing objects to dislodge the fruit. Other studies have reported similar results (Schreckenberg, 2004; Ruiz-Pérez et al., 1997). In southern Africa, indigenous fruits contribute on average $42 \%$ to the natural food basket that rural households rely on.

A total of 55 species were recorded, belonging to 47 genera and 30 families distributed in the two agro - ecological zones. They are categorized into three types: fruit for direct consumption, fruit used for spice or for culinary and fruits for medicinal uses. Anacardiaceae, Annonaceae and Mimosaceae are the most frequent families representing $31.03 \%$ of the families. Apema et al.
(2009) listed 43 wild edible fruit species in Central African Republic.

From the ecological point of view, two types of species are distinguished according to their ecological niches: species from the dry area and species for the humid forest. The fruit tree species colonizing the humid forest are represented by Ricinodendron heudelotii, Xylopia aethiopica and Tetrapleura tetraptera.

\section{Farmer Preferences}

Farmers' preferences vary according to agroecological zones. In the Adamawa region, $V$. doniana, was the most preferred $(100 \%)$ while $X$. americana $(85.70 \%)$ and $Z$. mauritiana $(94.12 \%)$ are preferred in the North and the Far North respectively. $V$. paradoxa, $A$. senegalensis, $P$. biglobosa, Detarium microcarpum, Borassus aethiopum and $X$. americana were known in the three provinces. A. digitata, B. aegyptiaca and $H$. thebaica were cited only in the North and the Far North provinces, while A. latifolium, $L$. owariensis, $S$. guineensis var. macrocarpum, Ricinodendron heudelotii, Tetrapleura tetraptera and Xylopia aethiopum were listed only in the Adamawa region. In the same region, $T$. indica and Z. mauritiana were found only in home gardens. Similar results have been reported by Mapongmetsem et al. (1997) and TchiegangMegueni et al. (2001) in previous studies. The Bafwabula in Congo rank Landolphia species among the most important wild edible plants (Termote et al., 2010).

All recorded species are woody, excepted $A$. latifolium, Cissus propulnea which are herbaceous plant. The most frequent species are Vitex doniana (76.67\%), Vitellaria paradoxa $(73.4 \%)$, Ximenia americana (65.67\%), Borassus aethiopum (65.57\%), Parkia biglobosa (62.66\%), Adansonia digitata (62.50\%), Balanites aegyptica (61,95\%), Ziziphus mauritiana (58,00), Syzygium guineense var. macrocarpum (54.66\%), Annona senegalensis (54.57\%), Landolphia owariensis (47.4\%), Aframomum latifolium. (45.8\%) and Tamarindus indica (32.56\%).Unanimity is done among the ethnic groups.

\section{Different type of fruits}

Fruit for direct consumption are those which are collected, crushed and consumed directly after harvested without any transformation. They constitute the majority of the species identified. Among them are Annona senegalensis, Borassus 
aethiopum, Carissa edulis, Cissus propulnea, Ficus spp., Vitex doniana, Vitex madiensis, Detarium microcarpum, Adansonia digitata, Ximenia americana, Syzygium guineense var. macrocarpum, Diospyros mespiliformis, Balanites aegyptiaca, Sclerocarya birrea, Nauclea latifolia, Aframomum latifolium, Tamarindus indica, Parkia biglobosa, Parinari curatellifolia, Hyphaene thebaica, Uapaca togoensis, Garcinia livingstonei, Gardenia aqualla, Grewia spp., Celtis integrifolia Landolphia owariensis, Ziziphus mstauritiana, etc. The second group of species is composed of spices. They are substances used to season the dishes and give them better taste (Lamien et al., 1996). The spices are cooked along with meals before eating. Their seeds are used in the preparation of various soups. The main species belonging to this category are Belschmedia anadioides, Berlinia grandiflora, Daniellia oliveri, Parkia biglobosa, Borassus aethiopicum, Amblygonocarpus andogensis, Balanites aegyptiaca, Fagara giletii, Piper guineense, Xylopia aethiopica, Ricinodendron heudelotii, Uvaria chamae, etc.

Among the fruit which are cooked before eating, is Canarium schweinfurthii for which the entire fruit is soaked in boiling water after cutting the heat source. During the soaking time, the pulp of the fruit became soft and is ready to eat. The seeds of Sclerocarya birrea are cooked and eaten like ground nuts.

For the other species, the seeds are fried and transformed into edible oil. The species involved in this category are Canarium schweinfurthii, Lophira lanceolata, Balanites aegyptiaca, Ricinodendron heudelotii and Vitellaria paradoxa. In addition to their use as fruits, many parts (bark, roots, leaves, etc.) are used in traditional medicine to cure some diseases. For example,the bark decoction of Sclerocarya birrea is taken by the population as a drug against diabetes. The medicinal value of this plant is scientifically well recognized (Tsabang, 2007). Lophira lanceolata and Hyphaene thebaica are also used by the same population to treat high blood pressure. In Central African Republic, the use of L. lanceolata to cure high blood pressure by the traditional healers has also been reported by Apema et al. (2009). The main species used as medicinal plants are Sclerocarya birrea, Carissa edulis, Vitellaria paradoxa, Hyphaene thebaica, Lophira lanceolata, Bridelia ferruginea, etc.

The species diversity is doubled by that of parts of the tree consumed (pulp, seed and entire fruit, leaves, roots). The pulp of the fruit (72.34\%) is the main part consumed by the population. The seed is consumed at $19.57 \%$. Among this, other parts of the species are consumed: pulp and seeds (6.52\%), pulp and leaves (6.52\%), pulp and roots (4.26\%). The species for which the pulp and seeds are both consumed, are Balanites aegyptiaca, Parkia biglobosa, Sclerocarya birrea. The seeds of A.andongensis and P.biglobosa are used in the preparation of a traditional spice called Dadawa in Cameroon (Mapongmetsem et al., 2010) and Soumboula in West Africa (Koura et al., 2010). In Togo, A. digitata seeds are used by Kabye and Nawdm in the preparation of various soups (Atato et al., 2010). Those for which both the pulp and the leaves are consumed are represented by Adansonia digitata, Balanites aegyptiaca and Borassus aethiopum.

\section{Traditional Fruit Processing}

The pulp of Z. mauritiana is crushed for the preparation of a local cake known as "Dakoua". Fermented seeds of P. biglobosa are used in the manufacture of a local spice called "Dadawa" in fufulde. This traditional magi is known in Burkina Faso as Soumbala (Lamien et al., 1996). The hypocotyls axes of $B$. aethiopum are highly appreciated and consumed as vegetable known as "Baji". The powder obtained from P. biglobosa fruits, $A$. digitata is used in the manufacture of a local drink. Fruits from B. aegyptiaca, A. digitata, H. thebaica, T. indica, D. microcarpa, Diospyros mespiliformis and Z. mauritiana are sun dried and can be conserved for a long period. The seeds of Vitellaria paradoxa are traditionally transformed into edible oil "butter" which has medicinal and cosmetic properties. Women often produce edible oils from the seeds of Balanites aegyptiaca, Canarium schweinfurthii and Lophira lanceolata.

Beside the nutritional aspect, all parts of these plants are used for medicinal needs of the population. Although the trees are known as multifonctional species, the major problem facing by women is lack of post harvest technology. As has been pointed out by Dewees and Scherr (1996), policies that promote the linkage between domestication and commercialization of non wood forest products are one of the important areas for 
further work. In this regard, there is also a need for better integration of the needs of the food and other industries from NTFPs with those of the subsistence farmers (Leakey et al., 2000).

Commercialization

Regarding the socio-economic importance, fruits of Adansonia digitata, Balanites aegyptiaca, Vitex doniana, Borassus aethiopica, Parkia biglobosa, Ximenia americana, Syzygium guineense var. macrocarpum, Sclerocarya birrea, Garcinia livingstonei, Diopyros mespiliformis, Vitellaria paradoxa and Xylopia aethiopica were the most frequent in markets. They are species with high market potentials. In Central African Republic capital Bangui, Canarium schweinfurthii, Landolphia owariensis, Piper guineensis, Tetrapleura tetraptera, Vitex doniana, Vitellaria paradoxa, Xylopia aethiopica, Ziziphus maritiana were among the most important species sold (Apema et al., 2009). In West Africa, the most important species commercialized are A. digitata, P.biglobosa, Tamarindus indica, B.aegyptiaca, V.paradoxa and V.doniana (Lamien et al., 1996; Atato et al., 2010, Agundez et al., 2010). The quantities commercialized as well as the price varied according to the type of fruits. In the Guinean Highland Savannahs (GHS) of Cameroon, 18.694 tons of fruits were sold for an average income of 2446.69 \$ (Table 3). Apema et al. (2010) reported that the fruits of Balanites aegyptiaca, Borassus aethiopum, Landolphia owariensis and Vitellaria paradoxa are among the most marketed fruits in Bangui.

In the Guinean Highlands Savannahs, quantities of fruits sold and their price vary according to the type, period of fructification. The packaging is by bags, basins and baskets. Transportation is doing by head, motorcycle, by donkey or by car. The fruits are wholesale or retailed. According to its size, the price of a fruit of Borassus aethiopum varies between 0.11 and $0.22 \$$. For Vitellaria paradoxa, it is 0.011-0.022\$. The other types of fruits are selling by pile, cup or grapes. A pile of Aframomun latifolium (7 to 10 fruits) or a grape of Santaloides afzelii costs 0.055\$. Concerning Ximenia americana, Syzygium guineense var. macrocarpum, Vitex doniana, Sclerocarya birrea, etc. women use very often a cup as a sell unit $(1.2-1.5 \mathrm{~kg})$ at $0.11 \$$. However from July to October, there is a significant difference between rural and urban markets concerning the value of species like Vitex doniana, Ximenia americana, Sclerocarya birrea, Borassus qethiopum. For these species, the price is doubled (for example, a cup of V.doniana costed 0.22\$).

Farmers trade the seeds of Berlinia grandiflora between Nigeria and Cameroon. A bag of seeds bought in Cameroon for 175.82-197.80 $\$$ is sold in Nigeria at 549.45-659.34\$. There are also transactions between Cameroon and Nigeria for the seeds of Amblygonocarpus andongensis and Parkia biglobosa. It can be mentioned that this trade remains informal.

\section{Food Value of Fruits}

The moisture content of the indigenous fresh fruits varies from $48.65 \%$ (Parkia biglobosa) to $89.06 \%$ (Sclerocarya birrea). The ten species with high considerably moisture content are comprised Ximenia americana, Carica papaya, Carissa edulis, Sclerocarya birrea, Landolphia owariensis, Syzygium guineense var. macrocarpum, Annona senegalensis, Santaloides afzelii and Aframomum latifolium. These fruits are often used traditionally for the production of juices. The high moisture content in these fruits indicates the difficulties in conserving them for a long period.

Vitamin $C$ value of the edible wild fruits was determined. On a weight basis, Scherocleria birrea had the higher value for vitamin C (13.60 $\mathrm{mg} / 100 \mathrm{~g}$ ) (Fig.2). The mean proportion of Vitamin $\mathrm{C}$ was $4.10 \mathrm{mg} / 100 \mathrm{~g}$ of fruits. The effects of vitamin $\mathrm{C}$ on enhancing iron absorption have been described. They have been linked to reduce cancer and heart diseases, low blood pressure, lower prevalence of the development of cataract, a heightened immunity against tropical diseases, thereby spurring a lot of interest in fruits containing high amounts of vitamin C (Simbo et al., 2010). It is one of the valuable vitamins for the human diet and because humans lost the ability to synthesize vitamin $\mathrm{C}$, fruits, vegetables and other plant materials are therefore the principal sources for human nourishment (Novakova et al., 2008 cit. Simbo et al., 2010).

Ash contents for fruits studied ranged from 0.19 to $11.50 \%$ respectively for Carissa edulis and Aframomum latifolium (Table 4). The fruits with the lowest ash contents were Carissa edulis, Sygygium guineense var guineense and Vitex madiensis with less than $0.40 \%$. The ash content of Carissa edulis in RDC is $0.031 \%$ (Malaisse, 2010). This result indicates that the ash content 
varies according to the locality. S. birrea is the best species in terms of ashes. These results suggest that the pulp of the species is very rich in minerals.

The mean lipid contents were found to be 0.50 - $21.04 \%$ respectively for Carica papaya and Carissa edulis (Fig. 3a). Similar results were presented by Loura et al. (2000) for Vitex doniana, Vitex madiensis and Ximenia americana. The species collected in this study are not potential sources of oils, compared to other nonconventional fruits. This result indicates that they can not be used as source of oil. The pulp of Dacryodes edulis from the grassfields of Cameroon contains 43 to $60 \%$ of lipids (Kapseu et al.,1998). The lipid content of Canarium schweinfurthii Engl from Ivory Coast is $44-45.5 \%$ (Chatigre Kouame \& Agbo Nzi, 1998).

Sugar is an important nutrient that supplies energy to the body. Vitex doniana. Santaloides afzelii and Aframomum latifolium (Fig. 3b) have high concentration of reducing sugar $(66.27 \%$, $66.24 \%$ and $38.63 \%$ of DW respectively). These fruits are therefore consumed for their sweet taste. Figure $3 \mathrm{c}$ shows the total soluble sugars contents of these indigenous fruits. Syzygium guineense var. macrocarpum contains the highest amount of total soluble sugars (93.98\% of DW). Ximenia americana, Olax subscorpioides, Carica papaya, Sclerocarya birrea, Annona senegalensis, Santaloides afzelii and Aframomum latifolium have more than $65 \%$ of total sugar and are used in traditional beverages.

The crude protein contents of the fruits studied are summarized in Figure 3d. The plant that contained the most protein on a dry weight basis of the edible part of the fruits was Aframomum latifolium (11.84 \% of dry weight). Annona senegalensis, Ximenia americana, Vitellaria paradoxa, Carissa edulis, Sclerocaria birrea, Parkia biglobosa, Landolphia owariensis, Santaloides afzelii, Syzygium guineense var. macrocarpum, Syzygium guineense var. guineense and Vitex madiensis contained $2-6 \%$ of protein. The lowest protein content was Carica papaya with $0.83 \%$ DW. The protein content of $S$. birrea in RDC is compared to the one obtained in the present study (Malaisse, 1997).

Concerning the mineral content, fruits with the highest iron content were Annona senegalensis $(48.07 \mu \mathrm{g} / \mathrm{g})$, Ximenia americana $(12.76 \mu \mathrm{g} / \mathrm{g})$ and
Landolphia owariensis $(6.95 \mu \mathrm{g} / \mathrm{g})$. The richest source of calcium was the fruits of Annona senegalensis $(558.74 \mu \mathrm{g} / \mathrm{g})$. For all the other fruits analyzed, the calcium content was low with the exception of Annona senegalensis and Ximenia americana which contained respectively 18.20 and $8.38 \mu \mathrm{g} / \mathrm{g}$, all the other fruits had magnesium contents in the $0.33-2.24 \mu \mathrm{g} / \mathrm{g}$ range. Levels of phosphorous in range of $103.44-804.02 \mu \mathrm{g} / \mathrm{g}$ respectively for Ximenia americana and Annona senegalensis are in agreement with the findings of Aboubakar (15). Indigenous fruit trees play an important role in rural health as a source of traditional medicine. It is clear that IFTS are extremely important to the welfare and health of the rural population. Expanded trade and post harvest technology could increase these attributes. Results obtained by the World Agroforestry Centre (ICRAF) indicate that substantial local, regional or even international market opportunities exist in west and central Africa for the NTFPs of many indigenous fruit trees and medicinal plants (Tchoudjeu et al., 2000).

\section{Conclusion}

The study demonstrates the high level of knowledge of the rural population related to the local biodiversity. Fruits of many indigenous plants are staples of populations of the northern region of Cameroon. They serve to supplement the nutrients provided by cereals and tubers. Among the 55 indigenous plants identified by the farmers, Adansonia digitata, Balanites aegyptiaca, Diospyros mespilimiformis, Haematostaphis barteri, Syzygium guineense var. macrocarpum, Ximenia americana, Ziziphus mauritiana, Vitellaria paradoxa, Sclerocarya birrea, Hyphaene thebaica, Vitex doniana, Annona senegalensis, Tamarindus indica, Landolphia owariensis, Parkia biglobosa and Aframomum latifolium are the "top 16"; the most preferred by the local population. They provide a vast array of products for consumption, medicine and trade. These species are socio-economically important. The nutritional analyses of the pulp of some of them give their potential value. This research gives equally the orientation on the species which will be considered in domestication programme. Physico-chemical properties should be taken into account while designing domestication programme. Despite the fact that those fruits are 
consumed and sold in local and regional markets, there is an obvious lack of information on processing of fruits into commercially viable products.

The domestication of these new crops would help to diversify and increase incomes and nutrition quality in these regions. There has been forest degradation which has resulted in disappearance of some indigenous species. The potential of the local fruit trees is considerable. Local edible fruits play an evident role by their diversified supply, even if individual contributions are limited in quantity and in time. The findings open the possibility for the selection of trees with high food value both at provenance and national levels for future domestication purposes for fruit production. The consumption of local fruit could lead to food security for the area along with the health benefits this brings to the population. Despite the multiple uses, some of them still remain underutilized in the light of the potential they have.

\section{Acknowledgements}

The work was undertaken through the funding of the Centre of Interface, Research and Applications for the Sustainable Development in Africa (CIRADA). The support is hereby gratefully acknowledged. The authors thank the anonymous reviewers for their suggestion which improved the quality of the manuscript.

\section{References}

Aboubacar, D. A. (1998). Etude de la composition physico-chimique de cinq fruitiers tropicaux de la savane de l'Adamaoua (Cameroun). Mémoire de Maîtrise, Université de Ngaoundéré.

AFNOR (1981). Association Française pour la Normalisation. Produits dérivés des fruits et légumes; jus de fruits. $1^{\text {ère }}$ édition; Recueil des normes françaises.

AFNOR (1986). Eaux; Méthodes d'essai. Recueil des normes françaises.

Agundez, D., Eyog Matip, O., Lamien, N., Ramamonjisoa, L. et Loo, J. (2010). Food tree species guidelines for genetic conservation and sustainable use. Com. International Symposium, Indigenous fruit trees for dryland Africa: domestication for use in a changing environment. Allada, Benin.
Apema, R., Mouzouloua, D. et Madiapevo, S.N. (2009). Inventaire préliminaire des fruits sauvages comestibles vendus sur les marchés de Bangui. In Systématique et conservation des plantes Africaines, eds. Van der Brugt, X., Van der Maesen, J. and Onana, J.M., pp. 113-319.Yaoundé, Cameroon.

Apema, R., Mouzouloua, D., Kosh-Komba, E. et Ngoule, Y. (2009). Plantes médicinales utilisées dans le traitement de l'hypertension artérielle par les tradipraticiens à Bangui. In Systématique et conservation des plantes Africaines, eds. Van der Brugt, X., Van der Maesen, J. and Onana, J.M. pp.305-311. Yaoundé, Cameroun.

Atato, A., Walak, Woegan, Y.A., Dourma, M., Batawlak, K. \& Akpagana, K. (2010). Usages et potentiel économique des fruitiers spontanés du Togo. Com. International Symposium, Indigenous fruit trees for dryland Africa: domestication for use in a changing environment. Allada, Benin.

Arnold, J. E. M. \& Ruiz-Perez, M. (2001). Can non timber forest products match tropical forest conservation and development objectives? Ecol. Econ. 39,437-447.

Banana, Y. A. (1996). Non-timber forest products marketing: field testing of the market information system methodology. In Domestication and commercialization of non-timber forest products in Agroforestry systems. Non-wood forest products (9). eds. Leakey, R.R.B., Temu, A.B., Menelyk, M. and Vantomme, P. pp.218-226.Nairobi, Kenya. Belcher, B., Ruiz-Perez, M. \& Achdiawan, R. (2005). Global patterns and trends in the use and management of commercial NTFPs: implications for Livelihoods and conservation. World Development, 33,1435-1452.

Bourely, J. (1982). Observations sur le dosage de l'huile des graines de cotonnier. Cot. Fib. Trop., 27 (2):183-196.

Chatigre Kouame, O. \& Agbo Nzi, G. (1998). Lipid composition of developing Canarium Schweinfuthii Engl. Seed. In $2^{\text {nd }}$ International Workshop on African pear improvement and other new sources of vegetable oils. eds.Kapseu, C.\& Kayem, G.J. pp.209-215. Ngaoundéré, Cameroun. Devani, M.B., Shishoo, J.C., Shah, A.S. \& Suhgka, N.B. (1989). Microchemical method: spectrophotometric method for microdetermination of nitrogen in Kjeldal digest. J. Assoc. Off. Anal. Chem. 72 (6): 953 - 956. 
Dubois, M., Gilles Hamilton, K.A., Rebers, P.A \& Smith, F. (1956). Colorimetric method for determination of sugar and related substances. Anal. Chem. 28:350 - 356.

Eyog Matig, O., Ndoye, O., Kengue, J., Owono, A. (2006). Les fruitiers forestiers comestibles du Cameroun. IPGRI/SAFORGEN/CIFOR. Cotonou, Bénin.

FAO (1999). Use and potential of wild plants in farm households, Food and Agriculture Organisation of the United Nations, Rome.

Harris, L.J. \& Ray, N.S. (1935). Determination of ascorbic acid in urine. Method using titration with 2, 6- dichlorophenol indophenol . Lancet, 1 (76):462.

Kalaba, F. K., Chirwa, P. W. \& Prozesky, H. E. (2008). The Contribution of indigenous fruit trees in sustaining the rural livelihoods and conservation of natural resources around Mwekera forest, Zambia. Com. $2^{\text {nd }}$ ANAFE International Symposium on Mainstreaming Climate Change into Agricultural and Natural Resources Management Education: tools, experiences and challenges. Lilongwe, Malawi du 28 juillet au 1er Août.

Kapseu, C., Mapongmetsem, P.M., Silou, T. \& Roques, M. (1998). Physico-chimie des fruits du safoutier (Dacryodes edulis) camerounais. Tropicultura 16-17 (1): 37-42.

Koura, K., Dissou, E. F., Daanon, J.-J., Djedji, M., Olou, M. et Ganglo, J. C. (2010). Usages ethnobotaniques de Parkia biglobosa au NordBénin. Com. International Symposium, Indigenous fruit trees for dryland Africa: domestication for use in a changing environment. Allada, Benin.

Lamien, N., Sidibe, A. and Bayala, J. (1996). Use and commercialiwation of non timber forest products in western Burkina Faso. In Domestication and commercialization of nontimber forest products in Agroforestry systems. Non-wood forest products (9). éds. Leakey, R.R.B., Temu, A.B., Menelyk, M. and Vantomme, P. pp.65-72.

Leakey, R. R. B., Greenwell, P. and Hall, M. N. (2000). Domestication of indigenous fruit trees in West and Central Africa. In Proceed. $3^{\text {rd }}$ International Workshop on the improvement of Safou and other non-conventional oil crops. eds. Kengue, J., Kepseu, C. et Kayem, G.J. pp.7392. Yaounde, Cameroon.
Loura, B.B, Mapongmetsem, P.M., Nkongmeneck, B.A., Foko, J., Kapchie, N.V. \& Denedoumba, D. (2000). Caractérisation physico-chimique de deux Myrtaceaes alimentaires endémiques des savanes soudano - guinéennes (Adamaoua, Cameroun). Cam. J. Biol. Bioch. Sc. 10 (2):31-39.

Malaisse, F. (1997). Se nourrir en forêt claire africaine: Approche écologique et nutritionnelle. Les presses agronomiques de Gembloux /CTA.

Mapongmetsem, P.M. (1998). Potentialités des essences locales pour la domestication dans les savanes soudano - guinéennes du Cameroun. Com. Regional Workshop, on Diversification of smallholder Farming systems in West and Central Africa through cultivation of indigenous trees, ICRAF, Yaoundé, Cameroon.

Mapongmetsem, P.M., Tchiégang, C., Nkongmeneck, B.A., Kapseu, C. \& Kayem, G.J. (1997). Agroforestry potentials of the indigenous tree species in the northern Cameroon. Cam. Biol. Bioch. Sci. 7(1): 21-25.

Mapongmetsem, P.M., Hamawa, Y., Djeumene, P., Maissele, D., Kossebe, C.F., Ndoum, J. F., Nduryang, J.B., Bebbe, F., Bouba, D., Wouldata, S., Zigro, L. \& Barbi, M. (2008). Valorisation des plantes alimentaires sauvages dans les savanes soudano-guinéennes du Cameroun. In Développement de l'Agro-Industrie et création des richesses. Actes Conférence Internationale. éds. Kapseu, C., Mbofung, C.M. et Amvam Zollo, P. H. pp.50-61. Ngaoundéré, Cameroun.

Mapongmetsem, P.M., Tsingsabe, O., Keumeze, V. et Damba, A. (2010). Utilisation et commercialization des produits forestiers non ligneux par les communautés locales en zone soudanienne. In AETFAT, Antananarivo, Madagascar.

Noubissie Tchiagam, J.B., Nzié, J.P., Bellefontaine, R. et Mapongmetsem, P.M. (2011). Multiplication végétative de Balanites aegyptiaca (L.) Del., Diospyros mespiliformis Hochst ex. A. Rich. et Sclerocarya birrea (A.Rich.) Hochst. au nord Cameroun. Fruits 66(5): 327-341

Rodier, J. (1978). L'analyse de l'eau: Chimie, physico-chimie, bactériologie, biologie. $6^{\text {ème }}$ Edition; Dunod Technique; Paris France.

Simbo, D., De Smedt, S., Van Den Bilke, N., De Meulenaer, B., Van Camp, J. and Samson, R. (2010). Vitamin C content of Baobab fruits (Adansonia digitata L.) from Mali: opportunities for domestication and food security. Com. 
International Symposium, Indigenous fruit trees for dryland Africa: domestication for use in a changing environment. Allada, Benin.

Tchiegang-Megueni, C., Mapongmetsem, P.M., Akagou, Z.H.C. and Kapseu, C. (2001). An ethnobotanical study of indigenous fruit trees in northern Cameroon. Forests, Trees and Livehoods, 11:149-158.

Tchoundjeu, Z., Tonye, J. and Anegbeh, P. (2000). Domestication of key indigenous non-timber forest products: their economical and environmental potentials in degraded zones of West and Central Africa. In Proceed. $3^{\text {rd }}$ International Workshop on the improvement of Safou and other nonconventional oil crops. Yaounde, Cameroon. eds.
Kengue, J., Kepseu, C. et Kayem, G.J. pp.51-59. Ngaoundéré, Cameroun.

Termote, C., Bwama Meyi, M., NDjango, J. B., Van Damme, P. and Dhed'A Djailo, B. (2010). Use and socio-economic importance of wild edible plants in tropical rainforest around Kisangani, district Tshopo, Democratic Republic of Congo. In Systématique et conservation des plantes Africaines, éds. Van der Brugt, X., Van der Maesen, J. and Onana, J.M. pp.417-427. Yaoundé, Cameroun.

Tsabang, N. (2007). Etude ethnobotanique des plantes à vertus anti-diabétique et/ou antihypertensives au Cameroun. Thèse de Doctorat PhD., Faculté des Sciences, Université de Yaoundé

Table 1 Characteristics of the study sites

\begin{tabular}{llll}
\hline \multicolumn{1}{c}{$\begin{array}{c}\text { Site biophysical } \\
\text { characteristics }\end{array}$} & \multicolumn{1}{c}{ Adamawa } & \multicolumn{1}{c}{ North } & \multicolumn{1}{c}{ Extreme North } \\
\hline Latitude & $6^{\circ} 20^{\prime}-7^{\circ} 40^{\prime} \mathrm{N}$ & $8^{\circ} 00^{\prime}-10^{\circ} 00^{\prime} \mathrm{N}$ & $10^{\circ} 00-12^{\circ} 00^{\prime} \mathrm{N}$ \\
Longitude & $1^{\circ} 00^{\prime}-16^{\circ} 00^{\prime} \mathrm{E}$ & $12^{\circ} 00^{\prime}-15^{\circ} 00^{\prime} \mathrm{E}$ & $14^{\circ} 20^{\prime}-15^{\circ} 00^{\prime} \mathrm{E}$ \\
Altitude & $900-2100 \mathrm{~m}$ & $400-1100 \mathrm{~m}$ & $300-1000 \mathrm{~m}$ \\
Climate & Sudano - guinean & Sudanean & Sudano - Sahelian \\
Precipitations & $1400-1800 \mathrm{~mm}$ & $800-1000 \mathrm{~mm}$ & $600-800 \mathrm{~mm}$ \\
Vegetation & Shrubs to woody & Shrubs to woody & Shrubs to woody \\
& savanna, forests & savanna & savanna, Spine \\
& & & steppes \\
Agro-ecosystem & Guinean Highland & Sudano-sahelian & Sudano-sahelian \\
& savannah & & Tupuri, \\
Main ethnolinguistic & Dii, Mboum, Foulbe & Mboum, Fali, & Tum, \\
goups & Gbaya & Moundang, & Mundang \\
\hline
\end{tabular}


Table 2 Fruit tree species of the northern Cameroon

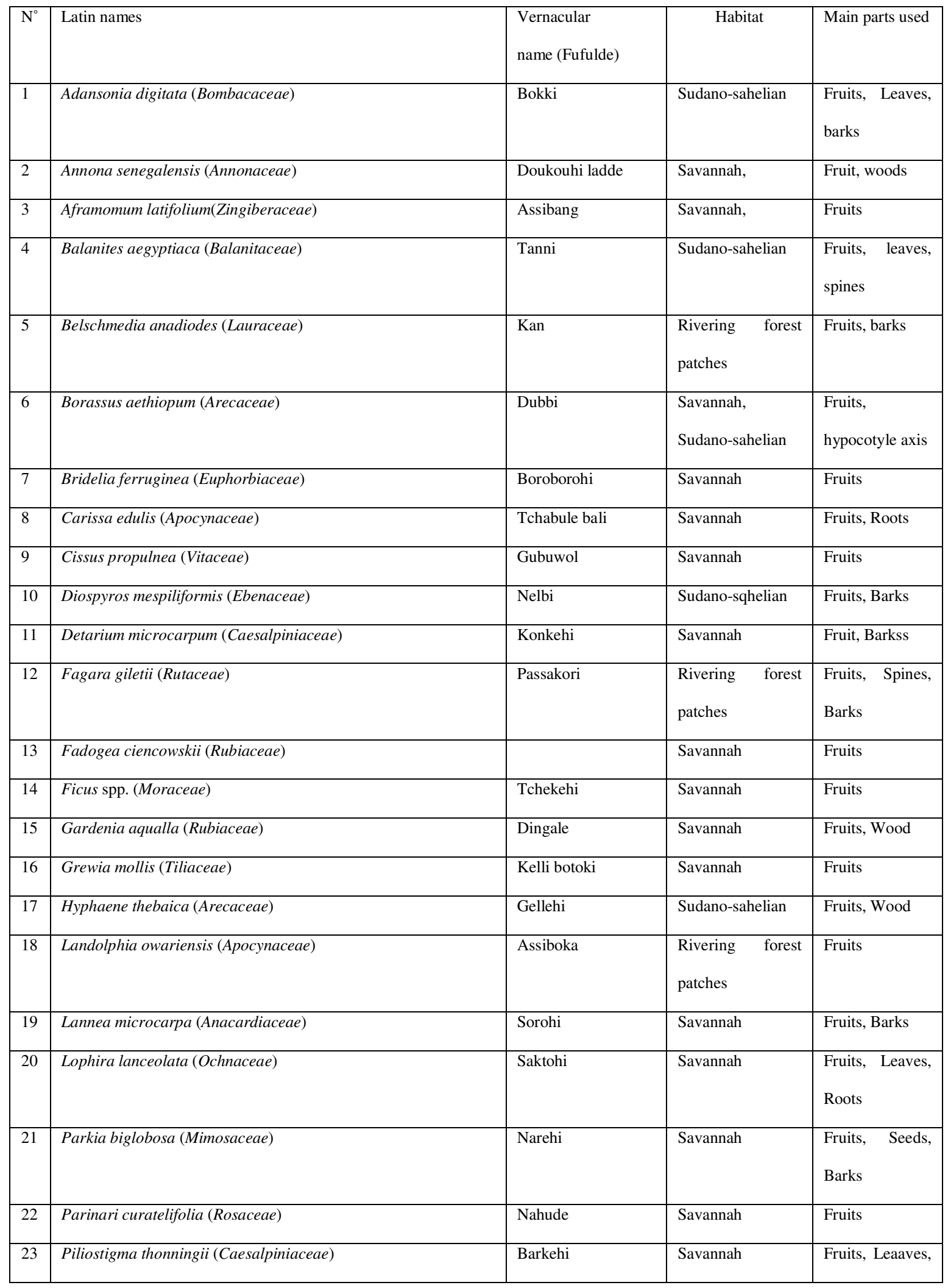




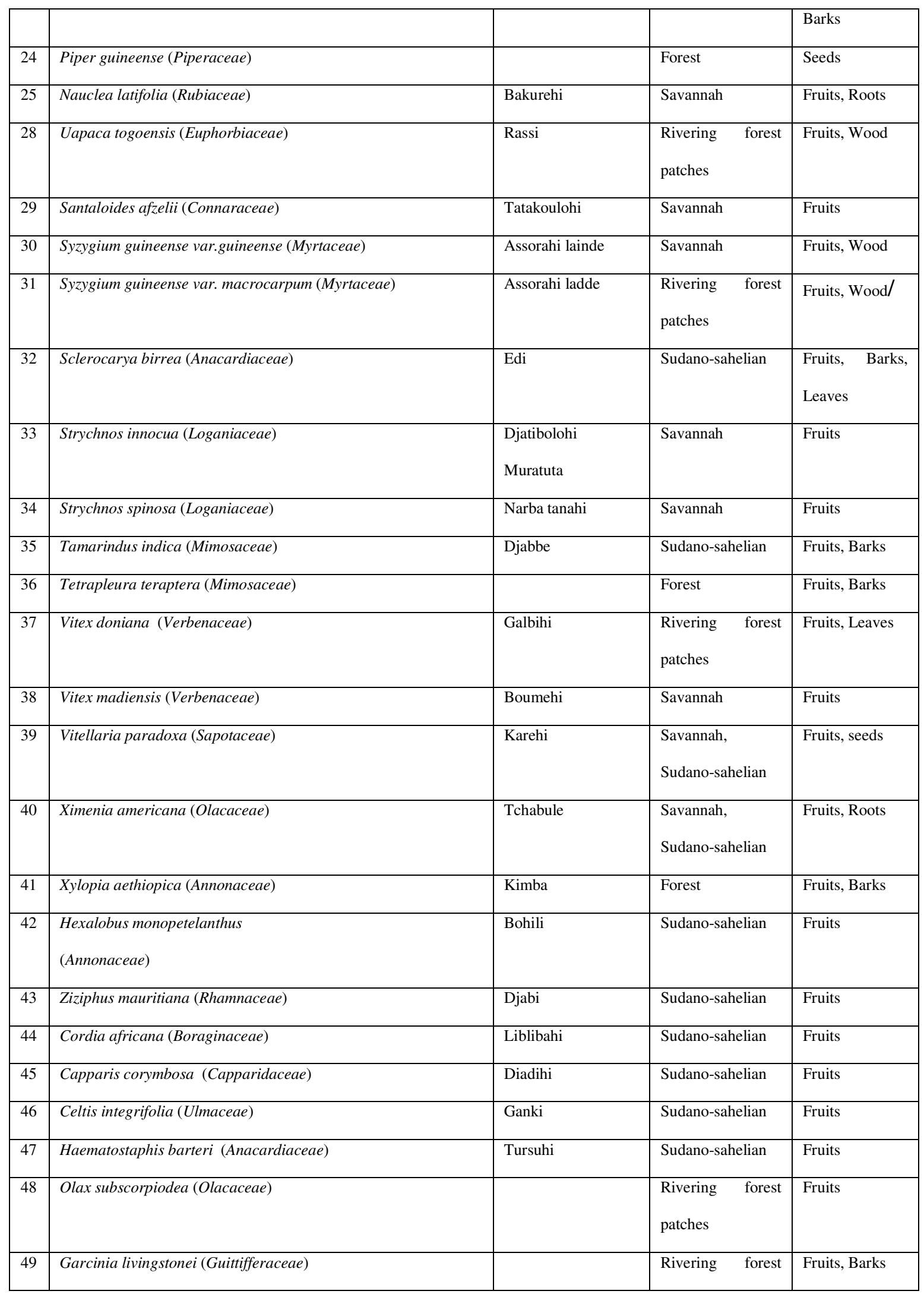




\begin{tabular}{|c|l|l|l|l|}
\hline & & & patches \\
\hline 50 & Amblygonocarpus andongensis (Mimosaceae) & Yake & Savannah & Fruits, Seeds, \\
& & & Revering forest & Fruits \\
\hline 51 & Uvaria chamae (Annonaceae) & Revering forest & Fruits, Barks \\
\hline 52 & Canarium schzeinfurthii (Burseraceae) & patches & Forest \\
\hline 53 & Ricitinodendron heudeloiti (Euphorbiaceae) & & Savannah & Seeds, Barks \\
\hline 54 & Daniellia oliveri (Ceasalpinaiceae) & Darman & Karlahi & patches \\
\hline
\end{tabular}

Table 3 Income generated by commercialization of fruits from April to October 2007 in the Guinean Highland Savannahs (GHS)

\begin{tabular}{lcc}
\hline Species & Quantity (kg) & Income (US\$) \\
\hline Aframomum daniellii & 115 & 6.32 \\
Aframomum latifolium & 128 & 6.87 \\
Borassus aethiopum & 424 & $46.59-42400$ \\
Landolphia owariensis & 93 & 10.22 \\
Parkia biglobosa & 1785 & 98.08 \\
Vitellaria paradoxa & 2983 & $65.56-163 ; 90$ \\
Vitex doniana & 8199 & $900.99-1801.98$ \\
Santaloides afzelii & 190 & 10.44 \\
Syzygium guineense var. & 1286 & $141.32-282.64$ \\
macrocarpum & & \\
Ximenia americana & 3490,5 & $383.57-767.14$ \\
Total & 18693,5 & $1669.96-3223.41$ \\
\hline
\end{tabular}


Table 4 Moisture and ash contents of 14 indigenous fruits

\begin{tabular}{lcc}
\hline Species & $\begin{array}{c}\text { Moisture content } \\
(\%)\end{array}$ & $\begin{array}{c}\text { Ash content } \\
(\% \mathrm{DW})\end{array}$ \\
\hline Annona senegalensis & 88.29 & $2.28 \pm 0.07 \mathrm{~cd}$ \\
Ximenia americana & 85.09 & $1.25 \pm 0.04 \mathrm{~b}$ \\
Syzygium guineense var. macrocarpum & 86.33 & $2.52 \pm 0.65 \mathrm{~d}$ \\
Aframomum latifolium & 86.46 & $11.5 \pm 0.16 \mathrm{f}$ \\
Scleroclerya birrea & 89.06 & $1.97 \pm 0.07 \mathrm{~cd}$ \\
Vitellaria paradoxa & 74.93 & $2.97 \pm 0.19 \mathrm{e}$ \\
Olax subscorpioides & 77.35 & $1.60 \pm 0.03 \mathrm{bc}$ \\
Carissa edulis & 87.96 & $0.21 \pm 0.03 \mathrm{a}$ \\
Landolphia owariensis & 82.61 & $1.52 \pm 0.05 \mathrm{~b}$ \\
Vitex doniana & 70.48 & $2.39 \pm 0.13 \mathrm{~cd}$ \\
Vitex madiensis & 78.06 & $0.31 \pm 0.01 \mathrm{a}$ \\
Santaloides afzelii & 85.94 & $3.11 \pm 0.14 \mathrm{e}$ \\
Parkia biglobosa & 48.65 & $3.27 \pm 0.01 \mathrm{e}$ \\
Syzygium guineense var. guineense & 82.80 & $0.4 \pm 0.01 \mathrm{a}$ \\
Moyenne & 80.25 & 2.52 \\
LSD.05 & & 0.43 \\
\hline
\end{tabular}

LSD =Least significant difference. Means with the same letter are not significantly different.

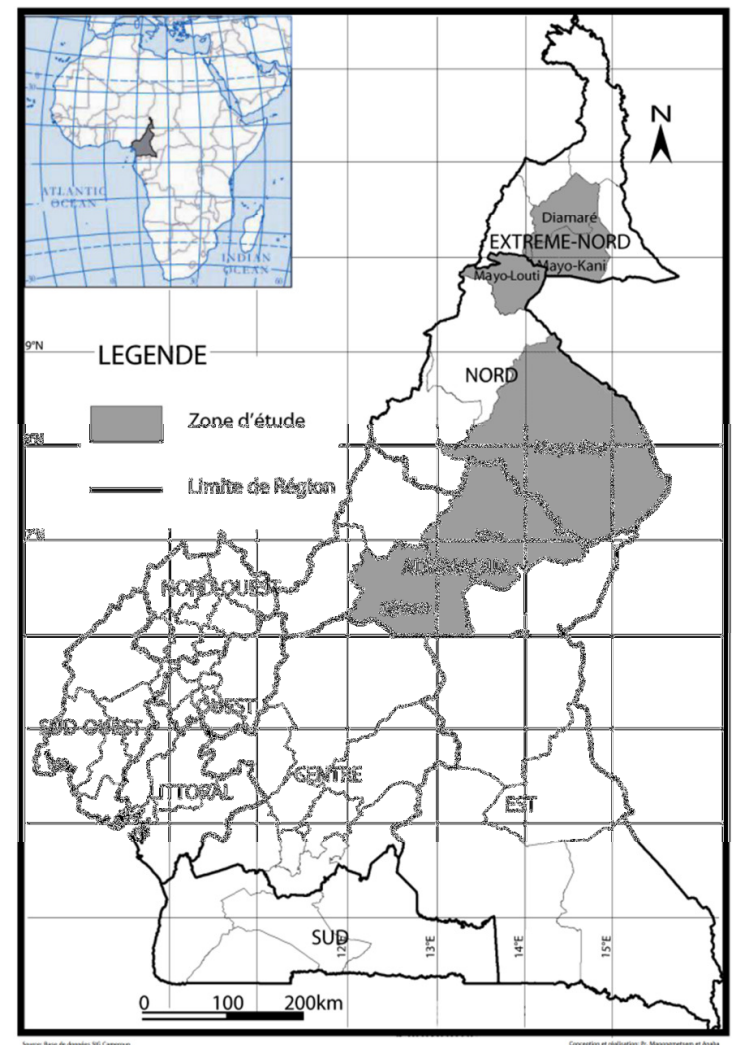

Figure 1 Localisation of the study sites 


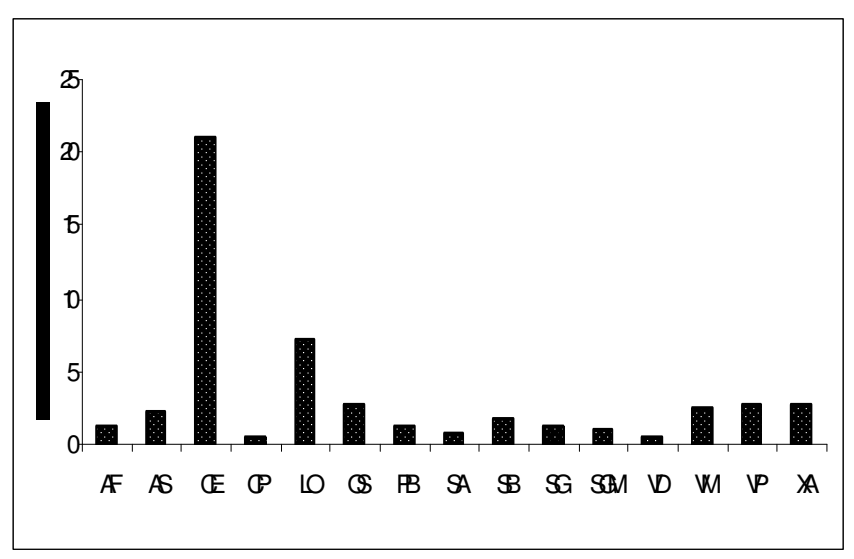

a)

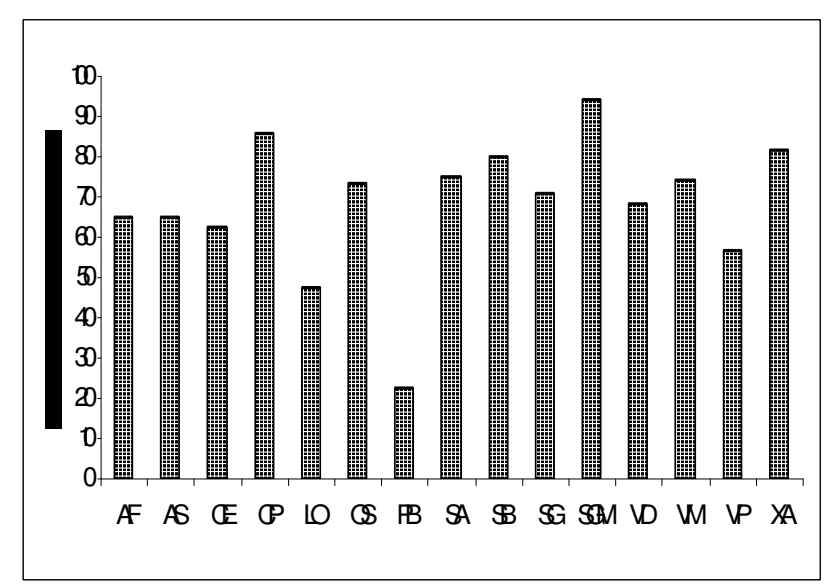

c)

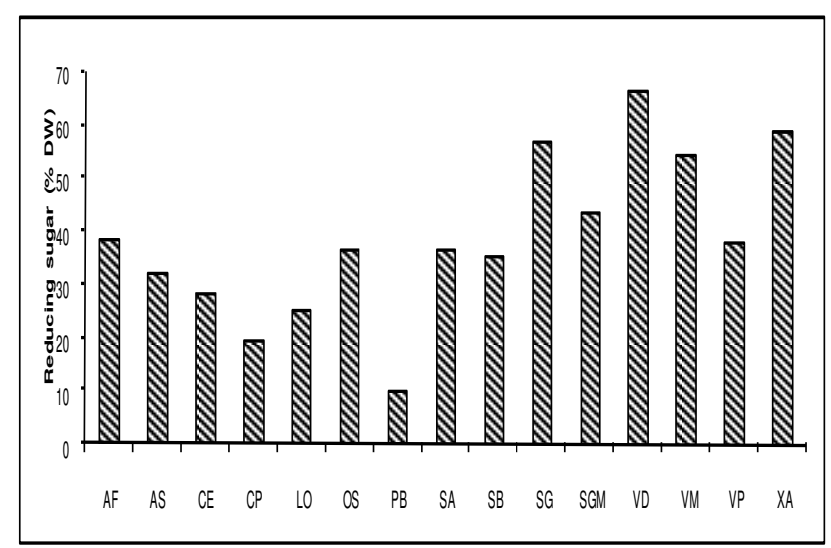

b)

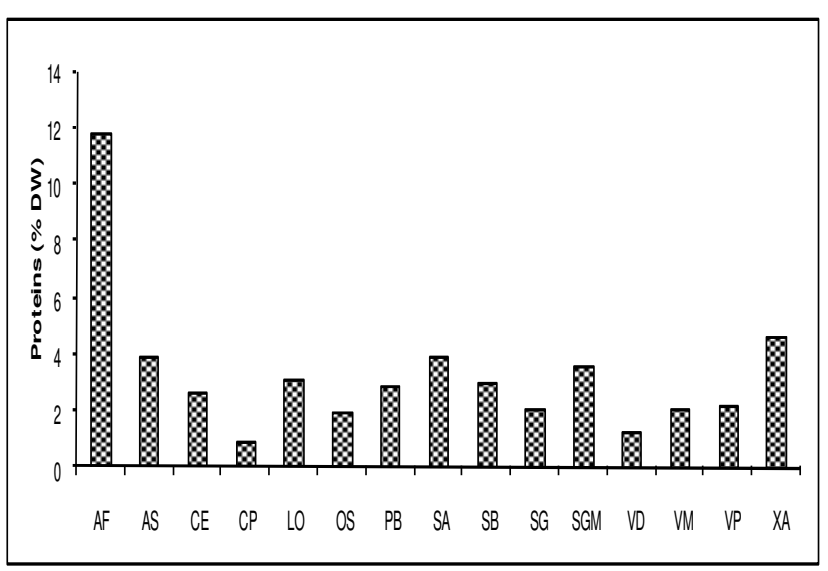

d)

Figure 2. Lipid (a), reducing sugar (b), total sugar (c) and protein contents (d) of Annona senegalensis (AS), Psidium guajava (PG), Syzygium guineense var. macrocarpum (SGM), Aframomum latifolium (AF), Sclerocleria birrea (SB), Vitellaria paradoxa (VP), Olax subscorpioidea (OS), Carissa edulis (CE), Landolphia owariensis (LO), Carica papaya (CP), Vitex doniana (VD), Vitex madiensis (VM), Santaloides afzelii (SA), Parkia biglobosa (PB), Syzygium guineense var. guineense (SG) and Ximenia americana (XA). 


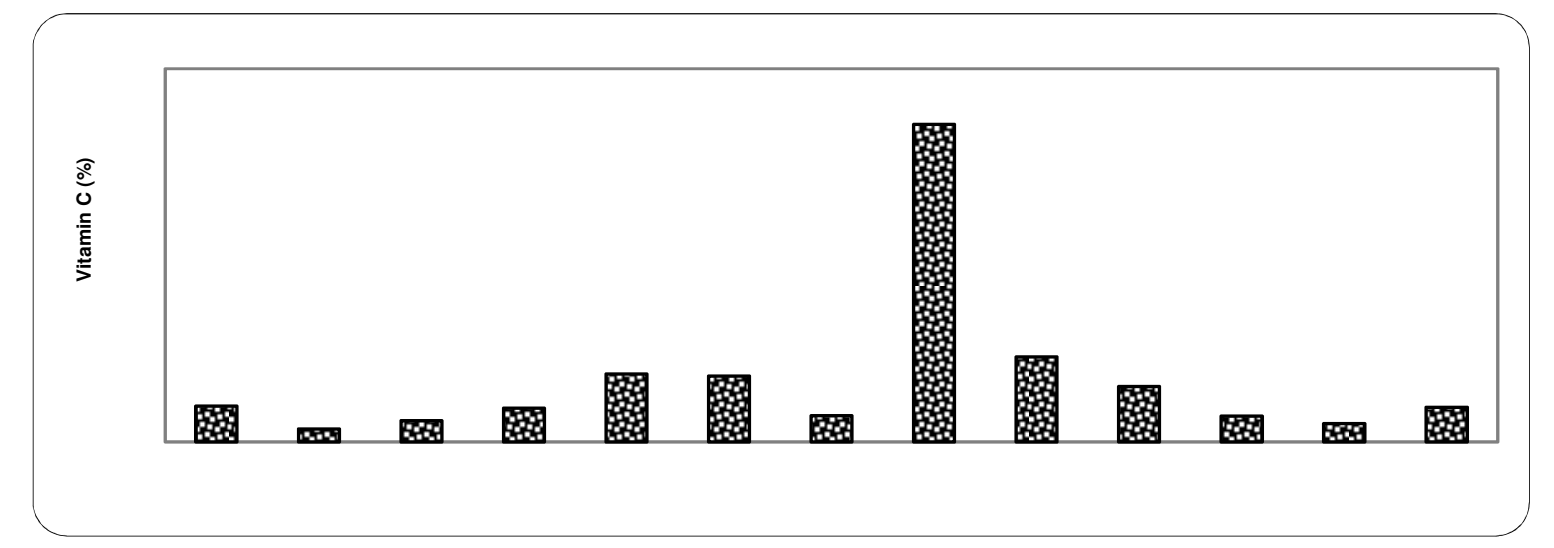

Figure 3: Content of vitamin C in Annona senegalensis (AS); Ximenia americana (XA), Psidium guajava (PG), Syzygium guineense var. macrocarpum (SGM), Aframomum latifolium (AL), Sclerocleria birrea (SB), Vitellaria paradoxa (VP), Olax subscorpioidea (OS), Carissa edulis (CE), Landolphia owariensis (LO), Carica papaya (CP), Vitex doniana (VD), Vitex madiensis (VM), Santaloides afzelii(SA), Parkia biglobosa (PB), Syzygium guineense var. guineense(SG). 